Review

\title{
Discourses of Consumption in US-American Culture
}

\section{Rita Turner}

Language, Literacy, and Culture Program, University of Maryland, Baltimore County, 421 Academic IV, 1000 Hilltop Circle, Baltimore, MD 21250, USA; E-Mail: rita.turner@umbc.edu; Tel.: +1-410-455-1000; Fax: +1-410-455-8947.

Received: 8 June 2010; in revised form: 23 June 2010 / Accepted: 12 July 2010 /

Published: 20 July 2010

\begin{abstract}
This paper explores varieties and examples of discourses of consumption, focusing primarily on US-American cultural discourses. The international community has in recent years developed an extremely valuable body of literature examining strategies for facilitating sustainable consumption; economic ramifications of varying consumption behaviors; attitudes and social structures that encourage or discourage sustainable consumption; approaches to consumption as a component of a sustainable or "green" lifestyle; and considerations of consumption practices in relation to inequities between North and South. The United States has made relatively few contributions to this body of literature thus far. But although the U.S. has not been one of the primary sources of academic literature on sustainable consumption, several types of discourses on consumption have become prominent in U.S. popular culture. These types of discourses include examinations of the moral status of consumption; investigations of the environmental or health consequences of modern consumption behaviors; explorations and critiques of green consumerism; and discourses that either construct or critique the commodification of the nonhuman world to produce objects for consumption. Throughout this paper I outline and offer examples of these strains of popular discourse, drawing on a newly-emerging body of U.S. literature and critically analyzing instances of discourse about sustainable consumption in film, television, internet, and print media. I conclude by examining new perspectives on sustainable coexistence that offer transformative possibilities for establishing relationships with the more-than-human world that are not based primarily on consumption.
\end{abstract}

Keywords: sustainable consumption; environmental discourse; green consumerism; critical discourse analysis 


\section{Introduction}

Turn on a television in the United States in April 2010, and you may see this McDonalds' advertisement:

An attractive young woman is sitting at a table, holding a burger. She brings it close to her face and turns it in her hands, looking at it. The expression on her face indicates rapt fascination with the burger. The then camera cuts to a close-up of the woman's hands holding the burger, as though we, the audience, are viewing the burger through her eyes. She turns it around and around in her hands. A man's voice narrates: 'McDonald's 'Bacon and Cheese Angus Third-Pounder'; as if it wasn't enough to make it with a full third-pound of 100-percent Angus beef, they had the audacity to use a bakery-style bun and crinkle-cut the pickles. There's no denying it - that's a third strip of bacon. Have they no shame?" The camera cuts back to a view of the woman holding the burger; she bites into the burger and smiles, as the narrator states: "Angus Axiom Number 39: It's an embarrassment of riches." The ad cuts to a close-up view of three of the burgers arranged together, as the narrator says, "The astonishing Angus Third Pounders: All Angus, all McDonald's" [1].

In this ad we find a number of messages about consumption. The ad highlights quantity and size. The imagery and language employed in the ad present this new burger as filled with more ingredients - and more meat - than other burgers. Using words like "full third-pound," "third strip of bacon," "riches," and "all Angus," the ad conveys the idea of abundance, even excess.

There are some, including health advocates, environmental activists, animal rights proponents, and those who are concerned about international equity between North and South, who might in fact find this burger, and the resource use, ethical issues, and consumption patterns in represents, to be shameful and embarrassing. But the ad un-ironically employs words like "audacity" and "astonishing," and phrases like "have they no shame" and "an embarrassment of riches," to express pleasure, even glee, at the excess the burger represents.

The narration in the ad seems to voice the thoughts of the woman holding the burger. And by showing the audience a view of the burger through the eyes of the woman and voicing these "thoughts" about the burger as we, through her, examine it closely, the ad positions the audience as the woman. We are told that not only does she feel this way about the burger, but that, since she is an extension of us, we feel this way about the burger, as well.

Through this technique the ad positions us, the audience, as "ideal subjects," communicating to us the attitudes we are expected to adopt [2]. And through the language used in the ad combined with the evident satisfaction of the woman and the pleased and self-satisfied tone of the voiceover narration, the attitudes we are expected to adopt are made clear: We want more. We enjoy wanting more. We revel in excess, we admire McDonald's lack of shame in offering us excess, and we take unabashed pleasure in seizing our opportunity to own and consume such excess.

This message exemplifies one of the most common, and perhaps one of the most dominant, attitudes about consumption present in the popular consciousness of the United States today. But it is not the only attitude. There is, in fact, a complex cultural dialogue taking place in the U.S., which both directly and indirectly explores questions of consumption. Messages about what to consume and why, and conversations about the value and place of consumption, show up in all facets of U.S. culture, through movies, films, music, advertising, popular books, and academic literature. Within the fabric of this 
ongoing dialogue are the interwoven threads of a number of different discourses and sub-discourses about consumption, which together create an intricate interplay of opposing narratives and competing ideologies about consumption. And in recent years, explorations of the motivations, tensions, and possibilities of sustainable consumption have added new discursive threads to the weave. Below I identity and describe five of these discourses on consumption, examining the contributions of both popular media and scholarly analysis in shaping US-American attitudes toward what and how, and for what purpose, we consume.

\section{Joining the Conversation}

As the urgent state of ecological degradation and social inequity worldwide raise ever-more pressing questions about the methods, patterns, and consequences of global consumption, the subject of sustainable consumption has a become a focus of serious international attention. This burgeoning international focus is evidenced by an increasing body of literature on the subject, including such compiled volumes as Exploring Sustainable Consumption, edited by Maurie Cohen and Joseph Murphy [3], and the comprehensive Earthscan Reader in Sustainable Consumption, edited by Tim Jackson [4].

Yet the U.S. has offered relatively few contributions to this growing body of literature. As Tim Jackson points out in his introduction to the Earthscan Reader in Sustainable Consumption, "The problem of consumerism had never been very far from the minds of US environmentalists.... But the terminology of sustainable consumption... seemed to have more resonance in Europe, in the years following the Rio conference, than it did in the US" ([5], p. 14). Marie Cohen echoes this point, stating, "Despite the attention now being devoted to sustainable consumption in [international] settings, the issue has received little formal political acknowledgement in the United States" [6].

Indeed, history demonstrates that the issue of consumption has, as Jackson puts it, "never been very far from the minds" of many in the United States. From the writings of Henry David Thoreau, to Veblen's 1899 text The Theory of the Leisure Class, to Garrett Hardin and The Tragedy of the Commons, to the 1971 Diet for a Small Planet and the 1973 Small is Beautiful [7-11], the U.S. has a long and rich tradition of questioning and critiquing consumption, the tracing of which would fall well beyond the scope of this paper. Still, in recent decades, as the subject of sustainable consumption has been taken up by a host of international authors, scholars and politicians in the U.S. have remained notably quiet on the subject (as Jackson and Cohen point out).

One recent text that does address questions of consumption and sustainability from a North American perspective is the 2002 edited volume Confronting Consumption [12]. Tim Jackson describes this text as a "landmark book," and the first "systematic attempt to articulate an approach to environmental policy in the US that took account of the question of consumption" ([5], p. 14). In it, editors Thomas Princen, Michael Maniates, and Ken Conca comment:

"Consumption and consumerism have long been consigned to the edges of polite talk among North Americans concerned about environmental degradation and the prospects for sustainability. How much, and what, do we consume? Why? Are we made happier in the process? How much is enough? How much is too much for the social fabric or health of the planet? Small wonder that these questions are addressed only obliquely, if at all. They are hard to answer, and when answers emerge they can be 
problematic, for they have an awkward tendency to challenge deeply held assumptions about progress and the "good life"; they call into question the very idea of consumer sovereignty, a cornerstone of mainstream economic thinking. They also challenge prevailing distributions of power and influence and smack of hypocrisy, coming as they so often do from those who consume the most. To confront such questions is to bite off, in one chunk, a large and vexing body of social, political, and cultural thought and controversy" ([12], p. 1).

Like Jackson and Cohen, Princen, Maniates, and Conca also assert that consumption rarely enters US-American discussions of sustainability. When it does, they say, it only enters "in nonthreatening ways, and most often in the form of calls for 'green consumption' or in support of some moral imperative to consume recycled or recyclable products," rather than in forms that address "escalating consumption levels and, especially, the roots of such escalation" ([12], p. 2). However, Princen et al. argue that this trend is beginning to shift. Citing popular texts like Juliet Schor's The Overspent American [13] as well public television documentaries and internet discussion groups, Princen, Maniates and Conca suggest that consumption is increasingly becoming a topic of concern in US-American, or North American, culture.

Still, Princen et al. remain critical of North America's still-limited efforts to join the conversation about sustainable consumption. One area they critique is public policy, which, they say, is dominated by "a deeply seated economic reasoning and a politics of growth that cuts across the political spectrum. According to prevailing economistic thought, consumption is nothing less than the purpose of the economy" ([12], p. 4). They argue that analysis and policy are both directed at production, in the sense of "supplying consumers with what they desire" ([12], p. 4), stating:

"The dominance of economistic reasoning and the pragmatism of growth politics conspire to insulate from policy scrutiny the individual black boxes in which consuming is understood to occur. As a result, an entire realm of questions cannot be asked. No one in public life dares-or needs-to ask why people consume, let alone to question whether people or societies are better off with their accustomed consumption patterns.... Consumption becomes sacrosanct... Goods are good and more goods are better" ([12], p. 5).

They also criticize the realm of environmental activism for a similar failure to effectively address consumption. They say, "Perhaps for reasons of political calculation, perhaps out of fear or an inability to challenge mainstream consumer values, there is a much greater willingness to examine the way things are done, especially the way things are produced, than to question the purposes served or not served by the doing of those things" ([12], p. 8).

Princen et al. next critique the academy, suggesting that it, too, has offered little insight, and that it has "come under the sway of economic reasoning" ([12], p. 9). They contend that "a large body of economic literature exists on "consumer theory," but its analytic goal is to better estimate demand curves, not to ask whether and how consumption patterns contribute to or solve social and environmental problems. Mainstream political science... is similarly blind to the consumption question." They point out that sociology and anthropology have done more to address questions of consumption, but critique these fields for presenting analyses implying that consumption is constituted entirely by social forces that are beyond the control of the individual or community. They also criticize psychology for using its examinations of personal satisfaction in relation to work and income to do nothing more than either critique materialism or "support product marketing" ([12], pp. 8-11). 
Still, despite the dominance of "economic reasoning" and the growth ideology, Princen, Maniates and Conca contend that "a significant portion of American society yearns for a less harried, less materialist, less time-pressed way of life, and that many know that their individual consumption and the consumption of their society as a whole are threatening environmental life-support systems." They also suggest that there is "a parallel longing for alternatives to conventional, political, economic, and ecological analysis that might more fully diagnose the challenges before us and sketch the paths to a future that works" ([12], p. 13). They offer their own text up as a step in meeting this need, explaining that their volume addresses consumption from three angles: "the social embeddedness of consumption; ...the linkages along commodity chains of resource use that shape consumption decisions; and ...the hidden forms of consuming embedded in all stages of economic activity" ([12], p. 14).

Tim Jackson also highlights the strain of unease about consumption that has long been present in US-American culture. He comments, "although the US may have lagged behind in adopting the terminology of sustainable consumption, North American writers have certainly not been slow in offering critiques of consumer society..." ([5], p. 15). His own reader contains selections from a number of such classic critiques of consumer culture, including Alan Durning's How Much Is Enough? and Juliet Schor's The Overspent American. Other contributions from U.S. authors offer alternative perspectives on the value of consumption, including an excerpt from Grant McCracken's 1990 book Culture and Consumption, in which, as Jackson summarizes, McCracken, "pushes the boundaries of the 'goods as communication' hypothesis to suggest that, far from leading to ignoble ends, the 'evocative power of things' can serve to express our highest hopes and preserve our noblest ideals..." ([5], p. 18).

Although U.S offerings of scholarly analysis on consumption in light of contemporary concerns about sustainability may still remain limited, the subject has not been completely ignored in U.S. society. In fact, if we expand our focus beyond the academy and examine popular culture, we find that questions about consumption continue to be a source of significant discussion and debate, perhaps as much or more than they have been in other periods of U.S. history.

Indeed, the discourses about consumption currently taking place in U.S. popular culture should not be overlooked. As argued by authors like Bourdieu, Althusser, Jenkins, McPherson, Shattuc, Gramsci, Mouffe, Williams, and many others [14-19], I contend that popular culture is a rich and valuable source of insight into the collective consciousness of a society. Since the discourses and practices of popular culture can serve to reflect, transmit, reinforce, reproduce, mask, highlight, reveal, or challenge power relations, ideologies, social structures, and conceptual frameworks within a given culture, and may in fact have a much greater impact on the opinions, beliefs, and practices of the public than does scholarly research, the patterns of thought about consumption and sustainability evident in U.S. popular discourse should be thoroughly investigated (a task of which this article may serve as only the most minimal beginnings).

In fact, Raymond Williams even argued that popular culture in the modern sense came about as a result of the Industrial Revolution and depends on the existence of a capitalist market economy [20], and as such its unique relationship to consumption makes it a fertile, if potentially problematic, field of inquiry into questions of a society's practices and beliefs regarding sustainable consumption.

In some instances popular discourse may operate to reproduce, maintain, and justify existing consumption patterns; in others, to capitalize on collective unease about modern consumption in order 
to generate economic gain; in still others, it may seek to problematize or challenge unexamined habits and attitudes toward consumption. But whatever its operation and motive, the public discourse that takes place through television, film, internet and print media, and advertising is a significant component of the collective conversation currently taking place in the U.S. For this reason, I seek here to review both scholarly and popular contributions to the conversation about consumption currently taking place in the United States.

The conversation is hardly unified. Indeed, arguments and assumptions on the subject are wide-ranging, diffuse, and often contradictory. So, since I have not yet encountered an attempt to map the full landscape of contemporary U.S. discourse on consumption, I offer my own brief outline of such a map here. Having reviewed recent academic and popular contributions to the discussion of consumption, I have created five categories to organize the varying approaches to the subject that have been adopted in the U.S. in recent years. This model may serve as a starting-place for incorporating the many disparate threads of discourse on this subject into an understanding of the "big picture" of where the U.S. stands on the subject of consumption, and of sustainable consumption.

Within the ongoing US-American dialogue are a few distinct discourses on consumption, and within each of these discourses or sub-discourses are a spectrum of debates, conflicting value claims, and a range of actors and forces at work, each engaging in efforts that are sometimes united, sometimes opposed, sometimes unconnected, all seeking to influence, reproduce, challenge, or transform US-Americans' attitudes and behaviors toward consumption. And now concerns about sustainable consumption are beginning to work their way, from different angles, into this mix, adding new dimensions to the conversation. Below I explore some of these discourses, and the ways that questions of sustainability have begun to enter into them.

\section{Discourse 1: More Is Better}

"Greed is good." While this sentiment may not be as popular now as when it was famously spoken in the 1987 film Wall Street [21], it remains a strongly embedded message in much of U.S. popular culture. Turn on most television networks or radio stations, or open most magazines, and you'll likely find a plethora of aspiration narratives extolling the glamour, excitement, beauty, and happiness that arise from and can be derived from material acquisition.

Such messages are part of one of the most long-standing and highly-visible discourses about consumption in US-American culture: the discourse surrounding the idea that "more is better." While pro-acquisition narratives form the centerpiece of this realm of discourse, it also encompasses a range of critical responses to this idea.

Indeed, discourse surrounding the notion of "more is better" has developed into a multi-layered conversation exploring, enforcing, and contesting attitudes toward quantity, quality, and desirability when it comes to commodities and consumption. On the one hand, this discourse includes arguments exalting the joy of acquisition, possession, and excess, as illustrated by the McDonald's commercial described above. And on other hand, discourse surrounding this idea also includes competing arguments which critique notions of continuous growth or argue that consumption is bad, immoral, or - at best - ineffective at generating the happiness it claims to offer. 
One critical contribution to this discourse is Don Mayer's essay "Institutionalizing Overconsumption" [22]. In it, Mayer argues that a series of dominant concepts in United States culture, including notions that "nations and corporations must grow in order to "progress,", that nature is no more than a storehouse of resources, that spirituality has no place in business, and that rational individuals "will strive to amass as much material wealth... as possible," all contribute to a process that encourages, supports, and institutionalizes overconsumption "as a way of life" ([22], p. 67). Mayer offers an illustration: "You only go around once in life,' the Schlitz beer commercial used to implore, 'So go for all the gusto you can!'” ([22], p. 67) For further evidence, he cites the 1995 book God Wants You to Be Rich [23].

Drawing on William Leach [24], Mayer contends that "the illusions created by the corporate dream merchants have become the new religion..." and that "in feeding the dreams and desires of material salvation here and now, corporations have deliberately created "the consumer," an ideal marketing target who rejects tradition, focuses on immediate gratification, and is steeped in desire for all things new" ([22], p. 68).

Mayer goes on to critique a number of legal and governmental policies that he argues are "systematically stimulating the addictive, irrational impulse to feed a spiritual emptiness with more and more 'goods"” ([22], p. 73). These policies include the protection of corporate free speech in the form of advertising, government contracts and subsidies that support large corporations and bolster the military-industrial complex, corporate support for political campaigns, corporate laws that put pressure on company heads to prioritize "short-term profit maximizing strategies" to satisfy shareholders ([22], p. 84), and tax policies that have "not rewarded conservation and investment" but have "on the contrary, tended to stimulate consumer borrowing and spending" ([22], p. 85).

Bill McKibben also asserts the argument that continuous "growth" is no longer a functional paradigm, at least for highly developed countries. In Deep Economy: The Wealth of Communities and the Durable Future, he states:

"...growth is no longer making most people wealthier, but instead [is] generating inequality and insecurity. And growth is bumping against physical limits so profound-like climate change and peak oil - that continuing to expand the economy may be impossible; the very attempt may be dangerous. But there's something else too, a wild card we're just now beginning to understand: new research from many quarters has started to show that even when growth does make us wealthier, the greater wealth no longer makes us happier" ([25], pp. 1-2).

McKibben argues for a reorientation toward local economies, where the priority is not "more," but rather durability, satisfaction, and "richer relationships." He comments, "The key questions will change from whether the economy produces an ever larger pile of stuff to whether it builds or undermines community-for community, it turns out, is the key to physical survival in our environmental predicament and also to human satisfaction" ([25], p. 2).

McKibben offers farmers' markets as an example of this reorientation beginning to take place in US-American culture, explaining:

"A single farmers" market... may not seem very important compared to a Wal-Mart, but farmers' markets are the fastest-growing part of our food economy. They've doubled in number and in sales and then doubled again in the last decade, suggesting new possibilities for everything from land use patterns to community identity" ([25], p. 3). 
Jack Manno makes a related argument, advocating for the goal of "getting more with less, not more stuff but more satisfaction..." ([26], p. 67). He makes a distinction between consumption efficiency, "the level of social welfare and personal satisfaction obtained per unit of energy and materials consumed" ([26], p. 67), and production efficiency, which is aimed at "decreasing the costs of inputs and/or increasing the value of outputs, thereby maximizing productivity" ([26], p. 68). Manno argues that increased production efficiency does not reduce consumption, but rather "lowers the costs of producing stuff and transfers the resulting savings toward additional consumption" ([26], p. 68). He offers an example of this phenomenon:

"Gains made in improving the fuel efficiency of the U.S. motor fleet... have been more than offset by trends toward larger vehicles, more cars per household, and more miles per car.... even though the automobile fuel efficiency in the United States improved considerably (34 percent) between 1970 and 1990 total fuel consumption during the same period increased by 7 percent" ([26], p. 68).

Manno suggests that, more and more in US-American culture, our primary strategy to fulfill needs is to develop commodities to address those needs. He calls this process commoditization, and he argues that we should instead seek to fill as many needs as possible through means other than developing and purchasing commodities.

Another component of this discourse is the well-established tradition of critiquing overconsumption and materialism. Authors taking this approach include Alan Durning and Juliet Schor, as mentioned above, as well as a host of others. Stuart and Elizabeth Ewen offer one such critique, arguing that consumerism has "engendered passivity and conformity. The add, "the logic of consumption... is embroiled in our intimacies; tattooed upon our hopes; demanding of our energies.... The insatiable urge for new things" [27].

In The High Price of Consumerism, Tim Kasser makes a related argument for the personally and socially destructive nature of modern consumption in the United States. He outlines his own research and that of others, to argue that "materialistic values" lead to reduced quality of life, sense of contentment, connection to family and community, and self-fulfillment. He argues that those who place a high value on the acquisition of material possessions are often attempting to compensate for emotional and psychological needs that were not fulfilled in their early lives, and he contends that materialism is an unsuccessful, and even destructive, coping mechanism for responding to unfulfilled needs, as those who organize their lives around materialist pursuits end up becoming more dissatisfied, less generous, less empathetic, more alienated from friends, loved ones, and their own culture, less interested in acting for the greater good, and less interested in preventing environmental degradation [28].

One cultural response to such feelings about the unsuccessful and destructive nature of materialistic pursuits has been the development of the "voluntary simplicity" movement, in which people choose to reduce their focus on material possessions and acquisition and reorient their lives away from work and money-making and toward self-fulfillment and "quality-time" with family and community. Michael Maniates discusses this movement, which he says "sows the seeds of collective challenge to fundamental dysfunctions of industrial society" and "resonates with the American deification of individual freedom" ([29], p. 99).

Stephen Zavestoski examines the voluntary simplicity phenomenon, as well. Studying participants in voluntary simplicity classes in the Pacific Northwest region of the United States, Zavestoski 
explores what motivates individuals to pursue voluntary simplicity, examining whether the primary motivation is one of environmental concern or personal dissatisfaction with a consumption-based lifestyle. He comments, "as consumption comes to dominate an individual's options for communicating information about the self, feelings of inauthenticity may emerge and compel alternatives to consumption as a means of self-identification" ([30], p. 173).

Still, while critiques of materialism represent a powerful component of this discourse, others argue that such approaches are unproductive, overly simplistic, or overly critical of individual actions and motivations. Maniates comments on the frequently-employed rhetoric of the immorality of consumption, arguing that "well-intentioned homilies" on rejecting materialism "too often overemphasize individual culpability... at the cost of frank talk about the political and economic structures that manufacture desire and lock us into patterns of overconsumption" ([29], p. 209). Lizabeth Cohen points out that consumerism has not always been motivated only be greed or profit, explaining that as consumer culture expanded in the U.S. after World War II, many US-Americans hoped that the new "enormous... capacities of mass production and mass consumption" would increase equality, opportunity, and quality of life for all [31]. And William McDonough argues that addressing sustainability need not be about restraining ourselves to consume less stuff, but rather about making better stuff that nourishes humans and ecosystems rather than depleting them [32,33]. (I elaborate on McDonough's argument in a later section.)

And these conflicting attitudes about the value of material acquisition play out across popular culture, as well. The McDonald's ad described above is far from unique, as U.S. pop culture presents its audience with a barrage of narratives reinforcing the value of "more." At the same time, there have been a number of recent pop culture offerings expressing critical takes on consumerism, as well. Books and movies like WALL-E, No Impact Man, Stuff: The Secret Lives of Everyday Things, and The Story of Stuff [34-38] each raise questions similar to those posed by the authors above. The photography of Chris Jordon offers another example; photo series like Jordon's Intolerable Beauty: Portraits of American Mass Consumption present stunning and astonishing images of the scope of US-American consumption and waste, conveying a clear and visually compelling critique of overconsumption [39].

The phenomenon of commoditization, as described by Jack Manno - in which the U.S. responds to problems by developing commodities to address the problems - was even satirized on a recent episode of the television show The Colbert Report. In the episode Stephen Colbert describes the fast-food restaurant chain KFC's current campaign in which they promise to donate fifty cents to support breast cancer awareness each time someone purchases a bucket of their fried chicken. Colbert mentions critics who argue that raising money for women's health by selling unhealthy food products is hypocritical, and in response to this criticism he states:

"There's an easy way to solve this dilemma: Yes, fried food may clog your arteries. So, after you buy the chicken, everyone should also buy Campbell's Soup, whose 'Address Your Heart' campaign raises money to fight heart disease. Of course, canned soup often has high levels of sodium, which can lead to kidney disease. That's why you should load up on Coca Cola, corporate partner of the National Kidney Foundation. Now, sugary soft drinks can contribute to diabetes, so, we all need to buy a Ford, global partner of the Juvenile Diabetes Research Foundation. And don't worry that trucks and SUVs hurt the environment, just buy a carton of Marlboros, because Marlboro is a major partner of Keep 
America Beautiful. Of course, smoking causes cancer, so you'll want to fight back, by buying a bucket of KFC" [40].

In each of these manifestations we see either a reinforcement or a challenge to the key underlying assumptions of this discourse: that "acquisition leads to happiness" and that, therefore, "more stuff means more happiness."

\section{Discourse 2: Consider Your Health}

Like the discourse surrounding the idea of "more is better," US-American culture contains other discursive threads that are organized around other messages about consumption. Another such discourse that is increasingly evident in the U.S. is centered around health.

One side of this discourse claims that consumption, particularly consumption of single-use, disposable items, it essential to good health. Ads for bottled water offer a prominent illustration of this message, as they frequently stress that their water is "fresh" and "pure" (see examples of this language in a bottled water ad I'll describe in a later section), implying that water from other sources, such as tap water, is less pure, less clean, and therefore less healthy [41,42]. Makers of cleaning products employ this message, as well, suggesting that deadly germs are filling our homes and can only be dealt with using their superior products, as evidenced by Lysol's advertising slogan "Disinfect to protect" [43].

In another example, the Kleenex tissue company has recently come out with a new product: a dispenser of single-use paper towels designed for home bathrooms. Kleenex advertises this product by reminding consumers that a traditional bathroom hand towel is used over and over again, implying that the towel picks up dirt and germs through these multiple uses. The Kleenex hand towel dispenser, by contrast, provides "a clean, fresh towel every time." They add, "your hands are only as clean as the towel used to dry them" [44]. Here again we see the common message that reusable items, which do not contribute to increased consumption, cannot possibly be as clean, safe, and healthy as commoditized alternatives.

But, as with other discourses about consumption, the discourse on consumption and health is not limited to one message or perspective. It, too, contains a range of competing narratives and counter-arguments. One of the most prominent opposing threads within this discourse focuses on the relationship between U.S. food production and eating habits and health. A growing contingent of sustainable food advocates are voicing concerns about the nutritional value and health consequences of the modern US-American diet, as well as raising questions about industrial food production and food justice. Fast Food Nation [45] is perhaps one of the most widely-known texts on this subject, and authors like Alice Waters, Michael Pollan, John Robbins, and Anna Lappé and Bryant Terry have published extensively on this topic, as well [46-49].

In his Vegan Soul Kitchen, Bryant Terry comments, "like most Americans, African Americans saw the globalization of agriculture and industrialization of food as a good thing. Cheap. Fast. Convenient.... But today we recognize the fallout from the food system —on our bodies, spirits, cultures, and communities - and it's time now to get back to the land" ([50], pp. xxiii-xxiv). Terry voices his hope to "return our focus to fresh, whole, local, seasonal, and sustainably grown real food and away from what author Michael Pollan calls 'edible foodlike substances' (processed, canned, packaged, fast, and industrial)" ([50], p. xxiii). 
And this exploration of food production, health, and sustainability has become even more visible with the appearance of several recent films that take up questions like those raised by the above authors, including Supersize Me, King Corn, Food, Inc., and the movie version of Fast Food Nation [51-54].

In each of these cases, again, we see a battle over assumptions about the relationship between health and consumption, as each text argues that particular consumption practices are important in order to maintain or achieve good health.

\section{Discourse 3: You Are What You Buy}

In a current television ad for the Dodge Ram truck, close-up images are shown of the large truck driving over rugged, rocky terrain, barreling through streams, and towing heavy objects like boats, trailers, and equipment, interspersed with images of a faceless man in camouflage unloading objects from the back of the truck, and shots of an interior filled with shiny wooden paneling and leather seats. Accompanying these images is a voiceover narration in which a forceful-sounding male voice states:

"The most powerful offer on earth has been extended: Ram Truck Month. Where a Hemi-V8 update at no extra charge plus zero percent financing gives you two tons of 'Get out of my way, I'm not backing down from anyone, or anything. Not while I'm inside of an iron fist wrapped in a velvet glove, called the most award-winning Ram Truck ever"' [55].

This ad exemplifies a third discourse on consumption in US-American culture, surrounding the idea "you are what you buy." The message communicated in this Dodge commercial is that the Ram truck is powerful, and that, by purchasing it, the consumer will become powerful, too. Through the imagery and language of the ad, including the use of words and phrases like "powerful," "two tons," "get out of my way," "I'm not backing down from anyone or anything," and "an iron fist," not to mention the name of the truck itself, "Ram," the ad suggests that this truck can overpower any force it meets. The underlying implication seems to be that life is an ongoing battle in which having more strength, more power, more might, is better, and that anyone who owns this truck will acquire its strength and might. Ram owners don't have to "back down from anyone," because being inside their truck means they are inside "an iron fist wrapped in a velvet glove." This fist becomes, by extension, their own fist, and having an iron fist means they can exert force over others and get their way. The Ram is powerful, therefore Ram owners are powerful: this concisely illustrates the idea "you are what you buy."

A host of authors have commented on the ways in which consumption can serve to construct and constitute identity, voicing a range of opinions about the value, importance, and dynamics of this phenomenon. Princen, Maniates and Conca affirm that consumer's choices "are not isolated acts of rational decision making," but are often "significant parts of an individual's attempt to find meaning, status, and identity." They point out that it is important to consider "the location of power in structuring those choices" ([12], pp. 14-15), stressing the role of contextual social forces in shaping consumption as a meaning-making strategy.

Stephen Zavestoski sums up some critiques of this modern connection between meaning, identity, and consumption, saying, "Post-modern theorists such as Baudrillard (1981,1983), Bourdieu (1984), Featherstone (1991) and Jameson (1984), see the proliferation of goods in consumer societies as resulting in schizophrenic individuals struggling to create identities in a world of transitory and 
ephemeral signs and meanings. The instability of the self in a post-modern consumer society, these theorists suggest, facilitates social stratification through consumption as a statement of difference" ([30], p. 175; [14,56-59]).

Another example of messages linking identity to consumption in popular culture can be found in a number of recent advertisements that draw connections between meat-eating and masculinity. In ads by Burger King, Hungry Man, and KFC, food like tofu, quiche, yogurt, and fruit smoothies are referred to as "chick food" and such foods, as well as small portions of food in general, are associated with stereotypically female behaviors, like going to the bathroom in groups and speaking in high voices. Eating large portions of meat, however, is identified as a "manly" activity, as is having a big appetite and consuming large amounts of food overall [60,62]. A number of texts have investigated this relationship between consumption and masculinity, and specifically between meat-eating and the construction of masculinity, including Carol Adams' The Sexual Politics of Meat [63] and Carole Counihan and Steven Kaplan's Food and Gender: Identity and Power [64], among others [65,66].

In the realm of sustainable consumption, the discourse of "you are what you buy" has obvious links to the formation of green identity through purchasing "green products," an increasingly popular but problematic notion I discuss in more depth in the following section.

Other authors add additional perspectives to this discourse, as well. While many voice concerns about the modern link between identity and consumption, and about the processes of commodification, commoditization, and consumerization [12], there are some who point out the creative possibilities of consumption. Dick Hebdige comments that mass culture "communicates through commodities" and it is "difficult to maintain any absolute distinction between commercial exploitation on the one hand and creativity/originality on the other" [67]. And Don Slater paints a more positive image of,

"the market as a place of desire without obligation, of intimate fantasy in the midst of impersonal anonymity, of spectacle, entertainment and play, as a place where dreams can flow across a multitude of objects without yet being fixed permanently on any one probably still provides the single most potent space in Western societies in which one dreams alternative futures and is released (utopicly) from the unthinking reproduction of daily life" [68].

As evidenced in these examples, texts operating within this discourse all highlight the clear connection between consumption and identity. Some present this connection as a source of promise, others posit it as socially destructive, and others employ the assumptions it contains in order to offer consumers a ready-made sense of self, one they can adopt simply by making a purchase.

\section{Discourse 4: Consume Responsibly}

The positive possibilities of consumption are highlighted - some might say exploited - in another area of discourse, as well. This discourse focuses on the idea of consuming responsibly. Examples of advertisement that draw upon this discourse are becoming more and more frequent. One such example, a recent print ad for Dasani water, a brand produced by the Coca Cola Company, shows an image of a Dasani bottle nestled amongst bright green, dew-sprinkled leaves at the top of a stem, as though the bottle were a flower or fruit growing from the plant. On the other side of the page in large text, the advertisement states: "Better by Design: Up to $30 \%$ made from plants." In smaller writing it continues: "The pure, crisp taste of DASANI now comes in a better bottle. Made from up to $30 \%$ plant-based 
materials and still a 100\% recyclable bottle, PlantBottle ${ }^{\mathrm{TM}}$ packaging brings you fresh-tasting water in a bottle designed with the planet in mind" [69]. By drawing on consumer concern over the environmental impact of plastic water bottles, this ad tells consumers that they can help the planet by buying more bottled water - as long as it's Dasani bottled water.

In another recent example, which also employs concerns about the environmental impact of bottled water (this time to sell water filters), the Brita company's recent ad campaign presents statistics about the vast number of disposable water bottles U.S. consumers dispose of, stating, "more than 60 million plastic water bottles are thrown away every day in the United States" [70]. Brita offers its filters as an alternative to bottled water, encouraging consumers to use Brita filters and reusable water bottles, rather than buying bottled water.

Indeed, advertising campaigns urging consumers to help the environment by buying "green" products form a significant component of this thread of discourse. In some cases, as in the Brita ad above, such messages may also be combined with suggestions for larger changes in behavior. This can be seen in the April 2010 issue of Glamour magazine, which offers three pages on "How to Create Less Trash." The feature includes tips like, "Use a Mug Instead of a Paper Coffee Cup," "Think Before You Buy," "Recycle Your Old Gadgets," "Try Fabric Cloths to Clean Up Around the House," "Drink Tap Water," "Eat More Whole Foods," "Have Two Vegetarian Meals Each Week," and "Eat What's in Season." And on the same pages are short pieces titled "How to Be a Green Shopper" and "We Love This Organic Beauty Stuff," a segment containing suggestions on "organic" beauty products to buy [71].

While many are encouraged by increased interest in and availability of products that are marketed as environmentally sound, a number of authors have critiqued the idea of "buying green" as a sustainability strategy. Authors such as J. Peter Brosius and Peter Mühlhäusler discuss greenwashing, a technique whereby a company promotes its products or practices as environmentally friendly, even if their actual environmental impact is far more significant and harmful than suggested [72,73].

Expressing a different critique of the "buy green" strategy, Michael Maniates critiques what he calls "individualization," an "increasingly dominant, largely American" tendency to respond to environmental problems with isolated, individual consumer activity. He states, "this response half-consciously understands environmental degradation as the product of individual shortcomings.... It embraces the notion that knotty issues of consumption, consumerism, power, and responsibility can be resolved neatly and cleanly through enlightened, uncoordinated consumer choice" ([74], p. 45). Maniates points out that "when responsibility for environmental problems is individualized, there is little room to ponder institutions, the nature and exercise of political power, or ways of collectively changing the distribution of power and influence in society..." ([74], p. 45). He further laments:

"In our struggle to bridge the gap between our morals and our practices, we stay busy-but busy doing what we are most familiar and comfortable with: consuming our way (we hope) to a better America and a better world. When confronted by environmental ills-ills many confess to caring deeply about-Americans seems capable of understanding themselves almost solely as consumers who must buy "environmentally sound" products (and then recycle them), rather than as citizens who might come together and develop political clout sufficient to alter institutional arrangements that drive a pervasive consumerism" ([74], p. 51). 
Maniates outlines some of the forces contributing to this process of individualization, which he contends include "the historical baggage of mainstream environmentalism, the core tenets of liberalism, [and] the dynamic ability of capitalism to commodify dissent..." ([74], p. 46).

Still, the discourse of buying responsibly goes much further than supporting or critiquing the practice of buying green products. Some instances of this discourse focus on encouraging consumers to engage in thoughtful, informed, and conscientious purchasing practices, which include but are not limited to buying products designed to be healthier for the environment than available alternatives. A primary example is the movement toward buying locally, as discussed by authors like Bill McKibben, which has drawn extensively on the idea of responsible consumerism.

One aspect of this "buy local" trend is local food movements, a topic McKibben discusses in depth. He comments on the enormous "consolidation and concentration" of food producers into large industrial agribusinesses, factory farms, and food distributors that has taken place in the United States, and is taking place elsewhere around the world as well. He points out that, while such consolidation has led to an important increase in abundance and efficiency, this modern food production system also has significant costs in areas like workers' rights, community, animal cruelty, food supply health and safety, and resource use ([25], pp. 61-66). He points out that supporting local food economies can help "remake American agriculture" ([25], p. 88), as well as providing a greater sense of personal satisfaction and community.

Meanwhile, Thomas Princen explores some impediments to informed consumption. He describes the practices of "shading" and "distancing," by which the full long-term costs of an item's production and consumption are hidden from the view of the consumer, and sometimes of the producer, as well. Princen comments, "Consumers in a dynamic, expansive economy are more likely to be insulated from the consequences of their choices. They are left with little basis for their decisions beyond price. This insulation occurs in part through the separating of production and consumption decisions along a chain of resource decisions..." [75].

As it has some overlap with critiques of overconsumption and questions of health and identity, the discourse of responsible consumption is manifested and explored in many of the same texts that employ the other discourses described above. Books and films like No Impact Man, Diet for a New America, Grub, Stuff: The Secret Lives of Everyday Things, and The Story of Stuff, Food, Inc., and King Corn, among others, all explore important questions of consumer responsibility and the transformative power of making thoughtful changes in consumption behavior.

David Goodman and Michael Goodman describe ways that green consumerism can produce this transformative quality, by serving to restructure "producer-consumer networks" into arrangements of "nature-society co-production" ([76], p. 98). They explore the "discursive and material projects" of such endeavors as organic agriculture, which, they say, "seek to re-configure... relational materiality by changing the underlying metabolic relations and the social practices in which these are embedded. Human and non-human entities are; 'translated' into alternative production-consumption networks" ([76], p. 98). In this way the discourse of responsible consumption raises, or at least hints at, the possibility of making significant changes in consumption practices and paradigms. Although one of the primary underlying assumptions of this discourse, that individual purchasing behavior is the path to positive social change, is, as Maniates points out, certainly problematic, Goodman and Goodman demonstrate that recognizing the symbolic, communicative, and material power of personal 
consumption in maintaining or transforming larger social and socio-environmental structures may be an essential step toward genuine sustainability.

\section{Discourse 5: Alternative Approaches to Consumption}

The notion of changing the roles and relationships of humans, nonhumans, and produced objects; of creating "alternative production-consumption networks"; and of using consumption as a transformative force, is the inspiration and origin-point of our final discourse on consumption, which explores alternative approaches to consumption.

One of the most notable contributors to this area of discourse is William McDonough. In his essay A Boat for Thoreau: A Discourse on Ecology, Ethics, and the Making of Things, McDonough encourages us to ask, "How do we find ourselves in kinship with nature? How do we recognize ourselves as a vital and responsible part of it? To see the world this way, and to begin creating things within that context, is an exciting prospect" ([32], p. 299). McDonough contends that our production and consumption strategies must go far beyond improving "eco-efficiency," adding that "from the 'Third World's' perspective, eco-efficiency is simply the 'First World' figuring out how to use the 'Third World's' resources longer” ([32], p. 303).

Building on principles such as "waste equals food" and "respect diversity," McDonough introduces the influential argument later explicated in his collaboration with Michael Braungart, Cradle to Cradle [33], arguing for "a new and inspiring vision of taking, making, using, and consuming in the world" ([32], p. 303). McDonough proposes designing things so that they will return safely into the "biological or technical cycle," that is, to design for a "cradle-to-cradle" life cycle, rather than the current "cradle-to-grave" life cycle ([32], pp. 306-307). He also suggests that the things we make should not simply "sustain where we are now" but should be restorative. As an example he asks:

"What is one of the best designs we know of for inspiration? How about a tree? How about a design that can accrue solar income, is fecund, produces habitat for all sorts of living things including people, provides fuel, food, and micro-climate, distills and transpires water, sequesters carbon, and makes oxygen? ... How many things have humans designed that make oxygen? Why not make a building that produces oxygen? Why not make a building that produces energy? We're not very bright or ambitious designers if we can't even emulate a tree, which nature has put right there in front of us as an obvious model" ([32], p. 307).

This perspective is perhaps the most recently-added discursive thread in the U.S., and it remains largely outside the awareness of popular culture. However, a few examples are beginning to emerge of products that employ this sort of sensibility. One brand beginning to adopt this approach is Sun Chips, whose recent ads inform us that "Sun Chips bags are now made with plants, so they're compostable." Their television and internet commercials show images of a Sun Chips bag buried beneath the soil. As viewers watch, the bag is shown in stop-action-style time progression to break down entirely. Once the bag has disappeared, a flower sprouts out of the ground where the bag was buried [77].

In another contribution to the discourse on alternative approaches to consumption, Jesse Tatum describes a segment of the U.S. population who build and install their own home power systems, positing that these individuals offer a model of "divergent choice," and that they suggest an untapped desire to actively connect to one's place, one's home, and one's lifestyle through direct engagement 
with one's own consumption technology [78]. In an exploration of related themes, the movie Garbage Warrior documents architect Michael Reynolds' long-standing development of "Earthships," sustainable, off-the-grid, ecologically embedded homes built out of reused materials [79].

Another angle on this discourse is presented by Marilyn Bordwell, who discusses the strategy of "culture jamming" originated by such groups as Adbusters. Bordwell explains that by promulgating "advocacy and parody ads" in print and television, culture jamming "aims to liberate the mental environment from the powerful grip of market-structured consciousness by reclaiming airwaves and public spaces to propagate ideas instead of plugging products" ([80], p. 238). As an example Bordwell describes:

“...imagine that you're home, settling in for a night of serious digesting in front of the television, having just gorged yourself at Thanksgiving dinner. You're looking forward to the long weekend, and plan to make your annual pilgrimage to the megamall tomorrow with the kids to get a jump on holiday shopping. As you surf the channels, an odd image appears on the screen: the front end of a smiling claymation pig growing out of a map of North America. The pudgy pink pig wiggles and snorts with glee as an ominous voice-over states: 'The average North American consumes five times more than a person from India.... Give it a rest, America. Tomorrow is Buy Nothing Day"” ([80], p. 237).

Bordwell tells us that many critics believe advertising has transformed civic culture into consumer culture. She quotes graphic design scholar Rick Poynor, who states, "Advertising"s right to colonise the physical environment of the street and act as primary shaper of the mental environment is taken for granted and there is no officially sanctioned public competition for the thoughts, beliefs, imagination and desires of the passer-by. Apart from other ads" ([80], p. 238). Bordwell explains some of the "guerilla tactics" of culture jamming activists as they fight to "reclaim... some small slice of public media channels for use by the people rather than by corporate interests" ([80], p. 246).

Another thread of this discourse on transforming consumption seeks to highlight, critique, and suggest alternatives to the exploitation, othering, and commodification of nonhuman animals and of the land. Authors like Wendell Berry, Peter Singer, Cathy Glenn, Joan Dunayer, and Mark Bekoff [81-85] are pioneering this avenue of discourse, arguing against existing cultural and discursive practices that frame nonhuman beings as no more than commodities and resources to be used. Instead, they advocate for acknowledging and respecting the subjectivity of nonhumans and the inherent interconnectedness of humans with the "more-than-human world" [86]. The recent film Avatar could arguably be read as an attempt to explore this sort of conception of the world.

Such a perspective, that respects and honors nonhuman beings and the land as family rather than raw materials and seeks "sustainable coexistence" [87], would necessitate a dramatic transformation in production and consumption practices, as suggested by Goodman and Goodman, and by McDonough.

\section{Next Steps}

The discourses outlined above, for all their complexity, nuance, and intertwined narratives, still represent only pieces of the ever-evolving cultural dialogue about consumption taking place in the United States. This dialogue remains incomplete; dominant, uncritical messages about consumption continue to outweigh counter-arguments; popular treatments of consumption are perhaps too rarely informed by a critical or scholarly awareness; and issues of sustainable consumption remain 
marginalized and underdeveloped. Still, as some of the examples above demonstrate, these discourses continue to expand, new voices continue to contribute to the conversation, and new questions, ideas, and possibilities are slowly gaining attention.

Further, for all their limitations, these discourses do raise questions about how and why we consume and how we should organize our consumption patterns in the future. They also communicate a great deal about the values that motivate our consumption, and in some cases they offer examples of values and hopes that could support greater efforts to shift toward sustainable practices.

As one of the most primary and universal ways that people interact with larger social, industrial, political, and environmental systems, and at the same time one of the most deeply personal acts of daily life, consumption practices form a unique point of intersection between the individual and the larger world. As such, they are likely to reflect the central values and ideologies at work within each person and each society. In this way, they offer a great opportunity to reflect on the structuring values of a society. From this perspective, the current state of US-American discourse on consumption may paint an unflattering picture of U.S. values, as so many of the instances of discourse described above seem to appeal to self-interest as the best, most important, or only value, and do not hesitate to commodify others, especially nonhumans and the land. Still, it may be possible to shift these structuring values, and by so doing, to shift consumption practices, as well. By reorienting our attitudes and belief systems around a critical and empathetic awareness of socio-environmental processes and a close affinity and personal identification with the interlinked living creatures and systems of the more-than-human world, we may be able to transform the underlying conceptual frameworks that shape our actions, including our choices about what and how we consume.

I have argued in prior works that such a shift in values may be essential in cultivating attitudes that engender sustainability in all aspects of society, and that education may be one of the primary venues we can utilize to help individuals develop the sorts of values, qualities, and habits of mind that I believe are necessary for interacting with others and with the more-than-human world in sustainable ways [88].

I contend that education which cultivates "critical ecoliteracy" may help people find ways to live in the world that are more thoughtful, respectful, and sustainable. Critical ecoliteracy involves engaging in critical and compassionate thought and questioning about socio-environmental systems and about the ways that human culture, language, and actions interact with the more-than-human world. I have defined eight qualities that I feel are essential components of critical ecoliteracy:

- Empathy - a deeply-felt understanding and compassion for the feelings and experiences of others, both human and nonhuman;

- Mutuality - a strong sense of shared identity, community, interconnection, and interdependence between humans and the more-than-human world;

- Ethical Consciousness - an ongoing commitment to questioning right and wrong and to considering the responsibilities we each possess in relation to others;

- Context — broad knowledge of the state of the world, and of the dynamics at work in shaping it, from a socio-environmental perspective;

- Critical Language Awareness - an examination of how language is used, by whom, and why, and how these uses of language affect our relationship to the more-than-human-world; 
- Cultural Perspective - exposure to the belief systems, foundational narratives, and practices of a range of cultures, past and present, to gain insight into perspectives that are different from the dominant American perspectives;

- Imagination - the ability to creatively construct alternative visions of how things could be and how we might live our lives; and

- Agency - an empowered sense of one's own capacity to act to bring about positive change.

By incorporating educational materials and strategies designed to cultivate these qualities into any and all educational endeavors across all subjects and grade-levels of schooling, it may be possible to cultivate attitudes that would lead to more compassionate and forward-thinking behavior. Conceiving of the world in ways that are critically aware and are informed by empathy, understanding, ethical responsibility, and creativity can, I argue, influence all aspects of how we each perceive the world and how we make choices about our actions, including whether we view the nonhuman world as a stockpile of commodities and resources for us to use and consume, or as co-inhabitants of the earth and co-participants in a planetary community.

While it may seem questionable whether the realm of consumption — an area so inextricably linked to personal desire - could ever be organized primarily around values like empathy, affinity, community, and concern for others, I believe that the resilient if underutilized human desire to care about something and someone beyond the self is a strong force. The seeds of this desire may already be present in many of the discourses seen above, and may simply need to be nourished and expanded. Take as an example the recent pop song "Billionaire" by Travis McCoy [89]. The lyrics of the song begin: "I wanna be a billionaire so fricking bad/ Buy all of the things I never had/ I wanna be on the cover of Forbes magazine/ Smiling next to Oprah and the Queen." As one listens to this song, it sounds at first like a classic aspiration narrative, expressing a desire for affluence, acquisition, security, and status as sources of personal happiness and encapsulating the self-interest based values that dominate much of US-American discourse on consumption. However, further into the song the lyrics continue: “everyday Christmas/ Give Travie a wish list/ I'd probably pull an Angelina and Brad Pitt/ And adopt a bunch of babies that ain't never had sh-t/ ...I'd probably visit where Katrina hit/ And damn sure do a lot more than FEMA did...." In this way the song takes an important turn, from expressing a desire simply for acquisition and personal pleasure to voicing an urge to help others. This urge may prove a powerful transformational force if given greater opportunity to flourish.

Indeed, if we engage in the work of trying to shift cultural ideologies toward more critically ecoliterate perspectives, we may discover that the result is more than to strengthen or reawaken the human desire to care about what is beyond the self. We may find that we can expand the boundaries of our very conception of "self." As we begin to identify with the others of the more-than-human world, we may start to see the "self" as part of a vast and inclusive "us," so that our happiness is revealed to be intricately bound up with the happiness and well-being of those we come to see as part of our planetary family. 


\section{References and Notes}

1. McDonald's Advertisement. TBS Television Network, 29 April 2010.

2. Fairclough, N. Language and Power; Longman: London, UK, 1989; p. 49.

3. Exploring Sustainable Consumption: Environmental Policy and the Social Sciences, 1st ed.; Cohen, M.J., Murphy, J., Eds.; Pergamon: Amsterdam, The Netherlands, 2001.

4. The Earthscan Reader in Sustainable Consumption; Jackson, T., Ed.; Earthscan: London, UK, 2006.

5. Jackson, T. Readings in Sustainable Consumption: Introduction. In The Earthscan Reader in Sustainable Consumption; Jackson, T., Ed.; Earthscan: London, UK, 2006; pp. 1-23.

6. Cohen, M.J. Sustainable consumption American style: Nutrition education, active living and financial literacy. Int. J. Sustain. Dev. World Ecol. 2005, 12, 407-418; Available online: http://www.informaworld.com/10.1080/13504500509469650 (accessed on 28 April 2010).

7. Thoreau, H.D. Walden and Other Writings; Atkinson, B., Ed.; Modern Library: New York, NY, USA, 2000.

8. Veblen, T. The Theory of the Leisure Class: An Economic Study of Institutions; The Macmillan Company: New York, NY, USA, 1912.

9. Hardin, G. The tragedy of the commons. Science 1968, 162, 1243-1248.

10. Lappé, F.M. Diet for a Small Planet; Zimmerman, K., Iwamoto, R., Eds.; Ballantine Books: New York, NY, USA, 1975.

11. Schumacher, E.F. Small Is Beautiful: Economics as if People Mattered; Harper \& Row: New York, NY, USA, 1973.

12. Princen, T.; Maniates, M.F.; Conca, K. Confronting Consumption. In Confronting Consumption, 1st ed.; Princen, T., Maniates, M.F., Conca, K., Eds.; The MIT Press: Cambridge, MA, USA, 2002; pp. 1-20.

13. Schor, J.B. The Overspent American: Upscaling, Downshifting, and the New Consumer, 1st ed.; Basic Books: New York, NY, USA, 1998.

14. Bourdieu, P. Distinction: A Social Critique of the Judgement of Taste; Harvard University Press: Cambridge, MA, USA, 1984.

15. Althusser, L. Ideology and Ideological State Apparatuses. In Cultural Theory and Popular Culture: A Reader, 4th ed.; Storey, J., Ed.; Pearson Education: Austin, TX, USA, 2009; pp. 302-312.

16. Hop on Pop: The Politics and Pleasures of Popular Culture; Jenkins, H., McPherson, T., Shattuc, J., Eds.; Duke University Press: Durham, NC, USA, 2002.

17. Gramsci, A. Selections from Prison Notebooks; Lawrence \& Wishart: London, UK, 1971.

18. Mouffe, C. Hegemony and Ideology in Gramsci. In Culture, Ideology and Social Process; Bennett, T., Mercer, C., Woollacott, J., Eds.; Open University Press: Buckinghamshire, UK, 1981; pp. 219-234.

19. Williams, R. Culture; Fontana: London, UK, 1981.

20. Williams, R. Culture and Society; Penguin: Harmondsworth, UK, 1963.

21. Stone, O. Wall Street; Twentieth Century Fox: Los Angeles, CA, USA, 1987. 
22. Mayer, D. Institutionalizing Overconsumption. In The Business of Consumption: Environmental Ethics and the Global Economy; Westra, L., Werhane, P.H., Eds.; Rowman \& Littlefield Publishers: Lanham, MD, USA, 1998; pp. 67-90.

23. Pilzer, P.Z. God Wants You to Be Rich: The Theology of Economics; Simon \& Schuster: New York, NY, USA, 1995.

24. Leach, W. Land of Desire: Merchants, Power, and the Rise of a New American Culture, 1st ed.; Pantheon Books: New York, NY, USA, 1993.

25. McKibben, B. Deep Economy: The Wealth of Communities and the Durable Future; St. Martin's Griffin: New York, NY, USA, 2008.

26. Manno, J. Commoditization: Consumption Efficiency and an Economy of Care and Connection. In Confronting Consumption, 1st Ed.; Princen, T., Maniates, M.F., Conca, K., Eds.; The MIT Press: Cambridge, MA, USA, 2002; pp. 67-99.

27. Ewen, S.; Ewen, E. Channels of Desire: Mass Images and the Shaping of American Consciousness; McGraw-Hill: New York, NY, USA, 1982; pp. 75-76.

28. Kasser, T. The High Price of Materialism; MIT Press: Cambridge, MA, USA, 2002.

29. Maniates, M. In Search of Consumptive Resistance: The Voluntary Simplicity Movement. In Confronting Consumption, 1st ed.; Princen, T., Maniates, M.F., Conca, K., Eds.; The MIT Press: Cambridge, MA, USA, 2002; pp. 99-235.

30. Zavestoski, S. Environmental Concern and Anti-consumerism in the Self-Concept: Do They Share the Same Basis? In Exploring Sustainable Consumption: Environmental Policy and the Social Sciences, 1st ed.; Cohen, M.J., Murphy, J., Eds.; Pergamon: Amsterdam, The Netherlands, 2001; pp. 173-189.

31. Cohen, L. A consumers' republic: The politics of mass consumption in postwar America. J. Consum. Res. 2004, 31, 236-237.

32. McDonough, W. A Boat for Thoreau: A Discourse on Ecology, Ethics, and the Making of Things. In The Business of Consumption: Environmental Ethics and the Global Economy; Westra, L., Werhane, P.H., Eds.; Rowman \& Littlefield Publishers: Lanham, MD, USA, 1998; pp. 297-317.

33. McDonough, W.; Braungart, M. Cradle to Cradle: Remaking the Way We Make Things, 1st ed.; North Point Press: New York, NY, USA, 2002.

34. Stanton, A. WALL-E; Pixar Animation Studios: Emeryville, CA, USA, 2008.

35. Beavan, C. No Impact Man: The Adventures of a Guilty Liberal Who Attempts to Save the Planet, and the Discoveries He Makes about Himself and Our Way of Life in the Process, 1st ed.; Farrar, Straus and Giroux: New York, NY, USA, 2009.

36. Gabbert, L; Schein, J. No Impact Man: The Documentary; Eden Wurmfeld Films: Los Angeles, CA, USA, 2009.

37. Ryan, J.C.; Durning, A.T. Stuff: The Secret Lives of Everyday Things; Northwest Environment Watch Seattle: Washington, DC, USA, 1997.

38. Leonard, A. The Story of Stuff: How Our Obsession with Stuff Is Trashing the Planet, Our Communities, and Our Health—and a Vision for Change; Free Press: New York, NY, USA, 2010.

39. Jordon, C. Intolerable Beauty: Portraits of American Mass Consumption; Chris Jordan Photography: Seattle, WA, USA, 2003; Available online: http://www.chrisjordan.com/ (accessed on 29 April 2010). 
40. The Colbert Report; Comedy Central: New York, NY, USA, 29 April 2010.

41. Dasani Advertisment. Glamour Magazine, April 2010.

42. About Nestle Pure Life; Nestle Pure Life: Wilkes Barre, PA, USA, 2009; Available online: http://www.nestle-purelife.us/about/default.asp (accessed on 30 April 2010).

43. Disinfect to Protect Homepage. http://www.lysol.com/ (accessed on 30 April 2010).

44. Kleenex® Tissues Homepage. http://www.kleenex.com/NA/Default.aspx (accessed on 29 April 2010).

45. Schlosser, E. Fast Food Nation: The Dark Side of the All-American Meal, 1st ed.; Harper Perennial: New York, NY, USA, 2005.

46. Waters, A. In the Green Kitchen: Techniques to Learn by Heart; Clarkson Potter: New York, NY, USA, 2010.

47. Pollan, M. In Defense of Food: An Eater's Manifesto; Penguin Press: New York, NY, USA, 2008.

48. Robbins, J. Diet for a New America; Stillpoint: Walpole, NH, USA, 1987.

49. Lappé, A.; Terry, B. Grub: Ideas for an Urban Organic Kitchen; Tarcher: New York, NY, USA, 2006.

50. Terry, B. Vegan Soul Kitchen: Fresh, Healthy, and Creative African-American Cuisine, 1st ed.; Da Capo Press: Philadelphia, PA, USA, 2009.

51. Spurlock, M. Supersize Me; Kathbur Pictures: Terre Haute, IN, USA, 2004.

52. Woolf, A. King Corn. ITVS, 2007.

53. Kenner, R. Food, Inc.; Magnolia Pictures, 2008.

54. Linklater, R. Fast Food Nation; Recorded Picture Company, 2006.

55. Dodge Ram Advertisement. WMU Television Network, 29 April 2010.

56. Baudrillard, J. For a Critique of the Political Economy of the Sign; Telos Press: St. Louis, MO, USA, 1981.

57. Baudrillard, J. Simulations; Foss, P., Patton, P., Beitchman, P., Translated; Semiotext(e): New York, NY, USA, 1983.

58. Featherstone, M. Consumer Culture and Postmodernism; Sage: London, UK, 1991.

59. Jameson, F. Postmodernism, or the cultural logic of late capitalism. New Left Rev. 1984, 146, 52-92.

60. I Am Man-Burger King Commercial; YouTube Video: San Bruno, CA, USA, 2007; Available online: http://www.youtube.com/watch?v=vGLHlvb8skQ\&feature=related (accessed on 27 April 2010).

61. Hungry Man TV Commercial; YouTube Video: San Bruno, CA, USA, 2008; Available online: http://www.youtube.com/watch?v=ZaPcBwmCtiM\&feature=related (accessed on 27 April 2010).

62. KFC Double down Commercial; YouTube Video: San Bruno, CA, USA, 2010; Available online: http://www.youtube.com/watch?v=TVLEB0lv1rw\&feature=youtube_gdata (accessed on 27 April 2010).

63. Adams, C.J. The Sexual Politics of Meat: A Feminist-Vegetarian Critical Theory, 10th ed.; Continuum: New York, NY, USA, 2000.

64. Food and Gender: Identity and Power; Counihan, C., Kaplan, S.L., Eds.; Harwood Academic Publishers: Amsterdam, The Netherlands, 1998. 
65. Holt, D.B.; Thompson, C.J. Man of action heroes: The pursuit of heroic masculinity in everyday consumption. J. Consum. Res. 2004, 31, 425-440.

66. Sobal, J. Men, meat, and marriage: Models of masculinity. Food Foodways 2005, 13, 135-158.

67. Hebdige, D. Subculture: The Meaning of Style; Methuen: New York, NY, USA, 1979; pp. 94-95.

68. Slater, D. Going Shopping: Markets, Crowds and Consumption. In Cultural Reproduction; Jenks, C., Ed.; Routledge: New York, NY, USA, 1993; p. 207.

69. Dasani Advertisment. Glamour, April 2010.

70. Take the FilterForGood Pledge to Help the Planet; BRITA: Oakland, CA, USA, 2008; Available online: http://www.brita.com/news/take-the-filterforgood-pledge/ (accessed on 29 April 2010).

71. How to do anything better guide: How to create less trash. Glamour, April 2010.

72. Brosius, J.P. Analyses and interventions: Anthropological engagements with environmentalism. Curr. Anthropol. 1999, 40, 277-310.

73. Mühlhäusler, P. Language of Environment, Environment of Language: A Course in Ecolinguistics; Battlebridge: London, UK, 2003.

74. Maniates, M. Individualization: Plant a Tree, Buy a Bike, Save the World? In Confronting Consumption, 1st ed.; Princen, T., Maniates, M.F., Conca, K., Eds.; The MIT Press: Cambridge, MA, USA, 2002; pp. 43-66.

75. Princen, T. Distancing: Consumption and the Severing of Feedback. In Confronting Consumption, 1st ed.; Princen, T., Maniates, M.F., Conca, K., Eds.; The MIT Press: Cambridge, MA, USA, 2002; p. 116.

76. Goodman, D.; Goodman, M. Sustaining Foods: Organic Consumption and the Socio-Ecological Imaginary. In Exploring Sustainable Consumption: Environmental Policy and the Social Sciences, 1st ed.; Cohen, M.J., Murphy, J., Eds.; Pergamon: Amsterdam, The Netherlands, 2001; pp. 97-119.

77. SunChips. Available online: http://www.sunchips.com/ (accessed on 30 April 2010).

78. Tatum, J. Citizens or Consumers: The Home Power Movement as a New Practice of Technology. In Confronting Consumption, 1st ed.; Princen, T., Maniates, M.F., Conca, K., Eds.; The MIT Press: Cambridge, MA, USA, 2002; pp. 302-315.

79. Hodge, O. Garbage Warrior; Open Eye Media: Devon, UK, 2007.

80. Bordwell, M. Jamming Culture: Adbusters' Hip Media Campaign against Consumerism. In Confronting Consumption, 1st ed.; Princen, T., Maniates, M.F., Conca, K., Eds.; The MIT Press: Cambridge, MA, USA, 2002; pp. 237-253.

81. Berry, W. Another Turn of the Crank: Essays; Counterpoint: Washington, DC, USA, 1995.

82. Singer, P. Animal Liberation; Ecco: New York, NY, USA, 2002.

83. Glenn, C.B. Constructing consumables and consent: A critical analysis of factory farm industry discourse. J. Commun. Inq. 2004, 28, 63-81.

84. Dunayer, J. Animal Equality: Language and Liberation; Ryce: Derwood, MD, USA, 2001.

85. Bekoff, M. Minding animals, minding earth: Old brains, new bottlenecks. Zygon 2003, 38, 911-941.

86. Abram, D. The Spell of the Sensuous: Perception and Language in a More-Than-Human World, 1st ed.; Vintage: New York, NY, USA, 1997.

87. Oziewicz, M. "We Cooperate, or We Die": Sustainable Coexistence in Terry Pratchett'S the Amazing Maurice and His Educated Rodents. Child. Lit. Educ. 2009, 40, 85-94. 
88. Turner, R. The discursive construction of anthropocentrism. Environ. Ethics 2009, 31, 183-202.

89. McCoy, T. Billionaire; Available online: http://currenthiphop.com/gucci_mane/songs/billionaire/ 7670 (accessed on 15 July 2010).

(C) 2010 by the authors; licensee MDPI, Basel, Switzerland. This article is an Open Access article distributed under the terms and conditions of the Creative Commons Attribution license (http://creativecommons.org/licenses/by/3.0/). 